BRITISH MEDICAL JOURNAL VOLUME 291 7 DECEMBER 1985

to progressive renal failure. Plasma phosphate and serum uric acid concentrations and blood pressure, however, were always within the normal range, and a renal biopsy specimen showed no evidence of interstitia nephritis and only minimal arteriolar hyalinisation. In the rat extensive rena ablation is followed by increases in glomerular capillary hydraulic pressure, glomerular capillary plasma flow rate, and single nephron glomerular filtration rate, and these changes may eventually cause glomerulosclerosis. Similar processes may have occurred in this case.

Children maintain stable renal function for up to 33 years after unilateral nephrectomy. ${ }^{4}$ Our patient had lost a large proportion of his renal substance 19 years before he developed renal failure, suggesting that the eventual development of glomerulosclerosis in human remnant kidneys depends on both the number of remaining nephrons and the interval since injury.

1 Chanutin A, Ferris ED. Experimental renal insufficiency produced by partial nephrectomy. 1 Control diet. Arch Intern Med 1932;49:767-87.

2 Brenner BM, Meyer TW, Hostetter TH. Dietary protein intake and the progressive nature of kidney disease: the role of haemodynamically mediated glomerular injury in the pathogenesis of progressive glomerulosclerosis in aging, renal ablation and intrinsic renal disease. $N$ Engl f Med
Med progressive gloment

3 Hostetter TH, Olson JL, Rennke HG, Venkatachalam MA, Brenner BM. Hyperfiltration in remnant nephrons: a potentially adverse response to renal ablation. Am J Physiol 1981;241: F85-93

4 Robitaille P, Mongeau J-G, Lortie L, Sinnassamy P. Long-term follow-up of patients who underwent unilateral nephrectomy in childhood. Lancet 1985; ;:1297-9.

(Accepted 4 September 1985)

Renal unit, Manchester Royal Infirmary, Manchester M13 9WZ

L R SOLOMON, MRCP, lecturer in medicine

N P MALLICK, FRCP, consultant physician

Department of Pathology, Manchester University, Manchester M13

W LAWLER, MRCPATH, senior lecturer in pathology

Correspondence and requests for reprints to: Dr Solomon.

\section{Metronidazole and Indian kala-azar: results of a clinical trial}

Visceral leishmaniasis is a disease of global importance, yet the choice of drugs available for its treatment is severely limited; so far there has been no satisfactory alternative to pentavalent antimony. Metronidazole is a time honoured drug with a wide margin of safety and a wide range of antiprotozoal activity. Anecdotal reports suggest that it may be effective in visceral leishmaniasis. ${ }^{12}$ We report our experience with this drug in Indian kala-azar.

\section{Patients, methods, and results}

We studied five men and five women with the disease. Their mean age was $26 \cdot 7$ (SD 9.0) years and mean weight $37.5(\mathrm{SD} \mathrm{5.0}) \mathrm{kg}$. After a thorough clinical examination and routine investigations bone marrow was obtained by sternal or iliac crest puncture and smears examined for amastigotes of Leishmania donovani.
Only parasitologically confirmed cases were studied. Patients with complications such as pulmonary tuberculosis, jaundice, and cardiac or renal failure were excluded, as were those who had ever received antimonials or any other specific reatment for kala-azar.

Each patient was given metronidazole for 12 days $-25 \mathrm{mg} / \mathrm{kg}$ daily by intravenous infusion for five days followed by $40 \mathrm{mg} / \mathrm{kg}$ daily by mouth in four divided doses for seven days. Patients were assessed at regular intervals and any who did not show a satisfactory clinical response within two weeks were switched to antimony. In other cases the final assessment was made at the end of four weeks, when the bone marrow was also re-examined. The duration of follow up ranged from one to 10 months.

Student's $t$ test for paired data was used to compare pretreatment and posttreatment values.

Six patients showed both clinical and parasitological evidence of cure and remained well for up to 10 months (table). Only two patients did not respond clinically. One patient (case 5) showed clinical but not parasitological evidence of cure, and another patient (case 7) withdrew from the trial just when her temperature had touched almost normal. Possibly a longer period of treatmen might have succeeded in these last two cases. There were no appreciable side effects in any patient.

\section{Comment}

In six out of these 10 cases the results may be said to have been excellent, while two might be given the benefit of doubt; two cases were clear treatment failures.

Though experimental and in vitro studies ${ }^{34}$ must have dampened the enthusiasm of many workers, we decided to pursue this study as clinical results do not always conform to experimental findings. We are reasonably gratified by the results.

In view of the remarkable safety of metronidazole we suggest that it is worth a trial as a first line drug in visceral leishmaniasis; if treatment fails the patient may easily be switched to pentavalent antimony. The optimum dose, duration of treatment, route of administration, and mode of action, however, remain to be defined.

We are grateful to $M / S$ Unichem Laboratories Ltd for liberal supplies of metronidazole and to Mr Amar Nath Jha for typing and retyping the manuscript.

1 Murphy KJ, Borg AC. Co-trimoxazole for systemic leishmaniasis. Lancet 1981;i:323-4.

2 Masramon JC, Aubia J, Lloveras J, Llorach I, Llorach M. Co-trimoxazole for leishmaniasis-or metronidazole? Lancet 1981;i:669.

3 Keithly JS, Langreth SG. Inefficacy of metronidazole in experimental infections of Leishmania donovani, L mexicana and Trypanosoma brucei brucei. Am F Trop Med Hyg 1983;32:485-96. 4 Neal RD, Croft SL. An in vitro system for determining the activity of compounds against the intracellular amastigote form of Leishmania donovani. I Antimicrob Chemother 1984;14:463-75.

(Accepted 27 August 1985)

Departments of Medicine and Microbiology, Darbhanga Medical College and Hospital, Darbhanga (Bihar) 846003 , India

MOHAN MISHRA, MD, FRCPED, professor of medicine

$B$ D THAKUR, MD, resident medical officer

MAHESHWAR CHOUDHARY, MD, associate professor of microbiology

Correspondence to: Professor Mishra.

\begin{tabular}{|c|c|c|c|c|c|c|c|c|c|c|c|}
\hline & \multicolumn{10}{|c|}{ Case No } & \multirow[b]{2}{*}{ Mean } \\
\hline & 1 & 2 & 3 & 4 & 5 & 6 & 7 & 8 & 9 & 10 & \\
\hline $\begin{array}{l}\text { Liver enlargement }(\mathrm{cm}) \text { : } \\
\text { Before treatment } \\
\text { After treatment }\end{array}$ & $\begin{array}{l}2 \\
0\end{array}$ & $\begin{array}{l}3 \\
0\end{array}$ & $\begin{array}{l}7 \\
3\end{array}$ & $\begin{array}{l}4 \\
0\end{array}$ & $\begin{array}{r}10 \\
3\end{array}$ & $\begin{array}{l}6 \\
4\end{array}$ & $\begin{array}{l}7 \\
1\end{array}$ & $\begin{array}{l}0 \\
0\end{array}$ & $\begin{array}{r}11 \\
6\end{array}$ & $\begin{array}{l}5 \\
4\end{array}$ & $\begin{array}{l}5 \cdot 5 \\
2 \cdot 1^{*}\end{array}$ \\
\hline $\begin{array}{l}\text { Spleen enlargement }(\mathrm{cm}) \text { : } \\
\text { Before treatment } \\
\text { After treatment }\end{array}$ & $\begin{array}{l}9 \\
2\end{array}$ & $\begin{array}{l}5 \\
2\end{array}$ & $\begin{array}{l}7 \\
3\end{array}$ & $\begin{array}{l}4 \\
0\end{array}$ & $\begin{array}{r}11 \\
4\end{array}$ & $\begin{array}{l}17 \\
15\end{array}$ & $\begin{array}{l}5 \\
2\end{array}$ & $\begin{array}{l}8 \\
4\end{array}$ & $\begin{array}{l}7 \\
0\end{array}$ & $\begin{array}{l}5 \\
3\end{array}$ & $\begin{array}{l}7 \cdot 8 \\
3 \cdot 5^{\star}\end{array}$ \\
\hline $\begin{array}{l}\text { Total leucocyte count }\left(\times 10^{9} /\right) \text { : } \\
\text { Before treatment } \\
\text { After treatment }\end{array}$ & $\begin{array}{l}1.4 \\
3.9\end{array}$ & $\begin{array}{l}2.5 \\
5.5\end{array}$ & $\begin{array}{l}2 \cdot 7 \\
6 \cdot 7\end{array}$ & $\begin{array}{l}3 \cdot 8 \\
6 \cdot 6\end{array}$ & $\begin{array}{l}2.5 \\
5.2\end{array}$ & $\begin{array}{l}1.9 \\
1.8\end{array}$ & $\begin{array}{l}2 \cdot 2 \\
3 \cdot 3\end{array}$ & $\begin{array}{l}4.6 \\
8.0\end{array}$ & $\begin{array}{r}5 \cdot 3 \\
10 \cdot 1\end{array}$ & $\begin{array}{l}5 \cdot 2 \\
5.7\end{array}$ & $\begin{array}{l}3 \cdot 21 \\
5.68^{\star}\end{array}$ \\
\hline $\begin{array}{l}\text { Haemoglobin }(\mathrm{g} / \mathrm{/}) \\
\text { Before treatment } \\
\text { After treatment }\end{array}$ & $\begin{array}{l}64 \\
86\end{array}$ & $\begin{array}{r}88 \\
110\end{array}$ & $\begin{array}{l}102 \\
115\end{array}$ & $\begin{array}{r}90 \\
116\end{array}$ & $\begin{array}{l}60 \\
70\end{array}$ & $\begin{array}{l}52 \\
72\end{array}$ & $\begin{array}{r}78 \\
100\end{array}$ & $\begin{array}{l}90 \\
96\end{array}$ & $\begin{array}{r}95 \\
120\end{array}$ & $\begin{array}{r}85 \\
110\end{array}$ & $\begin{array}{l}80 \cdot 4 \\
99 \cdot 5^{\star}\end{array}$ \\
\hline Day temperature became normal & 6 & 4 & 4 & 4 & 5 & $t$ & $t$ & $t$ & 6 & 5 & 4.9 \\
\hline Parasitological cure & Yes & Yes & Yes & Yes & No & $t$ & $t$ & $t$ & Yes & Yes & \\
\hline $\begin{array}{l}\text { Follow up: } \\
\text { Duration (months) } \\
\text { Relapse }\end{array}$ & $\begin{array}{l}10 \\
\text { No }\end{array}$ & $\begin{array}{r}6 \\
\text { No }\end{array}$ & $\begin{array}{r}7 \\
\text { No }\end{array}$ & $\begin{array}{r}6 \\
\text { No }\end{array}$ & $\begin{array}{c}1 \\
\text { Yes }\end{array}$ & $\stackrel{t}{t}$ & $\stackrel{t}{t}$ & $\stackrel{t}{t}$ & $\begin{array}{l}3 \\
\text { No }\end{array}$ & $\begin{array}{c}2 \\
\text { No }\end{array}$ & \\
\hline
\end{tabular}

† Switched to sodium stibogluconate at end of two weeks. In these three cases post-treatment values refer to those at end of two weeks. 